112 Романчукевич В.В. Економічні напрями модернізації...

2. Shushkova, Yu. "Public finances of Ukraine and their place in the financial system of Ukraine." Economics, planning and management in the branches, Scientific Bulletin of NLTU of Ukraine, no. 22 (14), 2012, pp. 345-350.

3. Zagorodnii, A. Financial Dictionary, Znannia, 2002.

4. The Constitution of Ukraine. Law of Ukraine "On Amendments to the Constitution of Ukraine, Veles, 2005.

5. Didkivska, L., and L. Golovlo State regulation of economy, Znannia-Press, 2000.

6. Moskalenko, V. "The essence of social protection and its place in the politics of the social state." Scientific notes, vol. 21, 2003.

7. Skurativsky V., and O. Paliy Social policy, UADU, 2003.

8. Shevchuk P. Social policy and social security, LRIDU UADU, 2003.

9. Tkachuk I. State finances, V. Stefanyk Precarpathian National University, 2015.

10. Bolotina, N. "Human right to social security in Ukraine: the problem of terms and concepts." Law of Ukraine, no. 4, 2000, p. 36.

11. Korienko, O. V. "Problems of budget financing of social sphere and ways of solution." Economic space, no. 46, 2011, pp. 172-179.

12. Zhuravsky, V. S. and others. Ukrainian Laws. Social Code of Ukraine, Logos, 1998.

13. Budget Monitoring. Analysis of Budget Execution 2017. USAID, www.ibser.org.ua. Accessed 18 Oct. 2019.

УДК 336.02

doi: 10.15330/apred.2.15.112-118

\title{
ЕКОНОМІЧНІ НАПРЯМИ МОДЕРНІЗАЦІЇ ДЕРЖАВНОЇ ФІНАНСОВОЇ ПОЛІТИКИ СТАЛОГО РОЗВИТКУ УКРАЇНИ
}

\author{
ДВНЗ "Університет банківської справи”, \\ вул. Андріївська, 1, м.Київ, \\ 04070, Україна, \\ тел.: (044) 462-53-05 \\ e-mail: ubs@ubs.edu.ua
}

\begin{abstract}
Анотація. Стаття спрямована на виявлення економічних напрямів модернізації державної фінансової політики сталого розвитку України. Досліджено п'ять основних вимірів формування сталого розвитку: енергетична безпека, інтеграція внутрішнього енергетичного ринку, економічний союз, прогресивна політика для використання глобалізації, правосуддя та основні права громадян. Встановлено, що міграція покращує процес, що сприяє сталому розвитку. Міграційна політика повинна будуватися на солідарності та відповідальності та матиме додаткову перевагу - зробити цінний внесок у економічний розвиток і ефективність у довгостроковій перспективі. Виходячи із досліджень п’яти основних вимірів, що стимулює розвиток економіки сформовано основні напрями покращення державної фінансової політики сталого розвитку: покращення інвестиційного клімату, формування єдиного цифрового ринку, входження в структуру Європейського енергетичного союзу. Автором сформовано основні індикатори економічного напряму фінансової політики сталого розвитку: ВВП на душу населення; видобуток енергетичної сировини; видобуток неметалевих та будівельних матеріалів; видобуток рудної сировини; частка невідновлюваної енергії у валовому внутрішньому енергоспоживанні; внесок електроенергії, виробленої з відновлюваних джерел енергії; виробництво електроенергії джерелами та паливом; енергоємність економіки; кінцеве споживання палива та енергії в галузях економіки, а також електроенергії в галузях економіки; виробництво радіоактивних відходів; продуктивність вантажів; продуктивність пасажирських перевезень; розрахунок проїзду відстані на душу населення громадським транспортом. Встановлено, що індикатори економічного напряму фінансової політики сталого розвитку
\end{abstract}


націлені на покращення економічного стану країни, оскільки саме кожен із вказаних індикаторів вказує на зростання/зменшення рівня економічного стану.

Ключові слова: сталий розвиток, державна фінансова політика, модернізація, індикатори економічного напряму, економіка.

\title{
Romanchukevych V.V. ECONOMIC DIRECTIONS OF STATE FINANCIAL POLICY MODERNIZATION FOR SUSTAINABLE DEVELOPMENT OF UKRAINE
}

\author{
State University of Banking \\ Andreevskaya, str. 1, Kyiv, \\ 04070, Ukraine, \\ tel.: (044) 462-53-05, \\ e-mail: ubs@ubs.edu.ua
}

\begin{abstract}
The article is aimed at identifying the economic directions of the state financial policy modernization for sustainable development of Ukraine. Five basic dimensions of sustainable development formation are investigated: energy security, integration of the domestic energy market, economic union, a progressive policy for the use of globalization, justice and the fundamental rights of citizens. In addition, it was found that migration improves the process that promotes sustainable development. Migration policy must be built on solidarity and responsibility and will have the added benefit of making a valuable contribution to economic development and efficiency in the long term. Based on five main dimensions of research that stimulates economic development, the main directions for improving the state financial policy of sustainable development have been formed: improvement of the investment climate, formation of a single digital market, joining the structure of the European Energy Union. The author has formed the main economic direction indicators of the sustainable development financial policy: GDP per capita; extraction of energy raw materials; extraction of nonmetallic and building materials; as well as ore; share of non-renewable energy in gross domestic energy consumption; contribution of electricity produced from renewable energy sources; production of electricity by sources and fuel; energy intensity of the economy; final consumption of fuel and energy in economic sectors, as well as electricity in economic sectors; production of radioactive waste; cargo productivity; productivity of passenger transportation; fare calculation per capita by public transport. It is established that the economic direction indicators of the sustainable development financial policy are aimed at improving the economic condition of the country since each of these indicators displays an increase/decrease in the level of economic status.
\end{abstract}

Keywords: sustainable development, state financial policy, modernization, economic direction indicators, economy.

Вступ. Забезпечення державної фінансової політики сталого розвитку неможливе без запровадження процесів, що забезпечують пріоритетні напрями створення скоординованої глобальної стратегії націленої на збереження та відновлення природних ресурсів, збалансування економічної системи, гармонійний розвиток всіх сфер суспільства. Все це потребує економічної підтримки та фінансування, що спрямоване на майбутній розвиток та досягнення стабільності фінансової системи сталого розвитку.

Постановка проблеми. Метою статті $\epsilon$ виявлення економічних проблем та формування напрямів модернізації державної фінансової політики сталого розвитку України. Основними методами дослідження $є$ аналіз, синтез, узагальнення та метод системного підходу.

Результати. Дослідження сучасних проблем сталого розвитку суспільства висвітлено у працях іноземних та вітчизняних науковців. Зокрема серед вітчизняних сучасників дослідження сталого розвитку доцільно відмітити праці Дорогунцов С. I. [2], Сфремова О. [1], Мельника Л.Г. [5], Трегобчука В. М. [8], Ральчука О. М. [2], 
Варченко О. М. [1], Даниленка О. С. [1] та ін. Досить детально зміст поняття сталого розвитку вивчала Котикова О. I. [4] та Шубравська О. [9]. Проте у працях вказаних вчених досить мала увага приділена державній фінансовій політиці сталого розвитку, хоча на практиці дана проблема потребує особливої уваги.

Стратегія енергетичного союзу ЄС має п'ять основних вимірів [7], спрямованих на забезпечення сталого розвитку. Відповідно до нових правил управління енергетичним союзом, пропонуємо розробити інтегровані національні енергетичні та кліматичні плани, що охоплюють ці п’ять вимірів на період з 2021 по 2030 роки, зокрема:

1. Енергетична безпека. При цьому доцільно відмітити, що енергозабезпечення піддається ризикам, які включають порушення з боку країн, з яких СС імпортує паливо, а також екстремальні погодні умови, промислові небезпеки, кібератаки, тероризм і гібридні загрози. Для запобігання та управління потенційними кризами енергетична система повинна бути більш стійкою. Солідарність і регіональне співробітництво, а також міжнародний зв'язок з країнами-постачальниками є ключовими для цього.

Основною гарантією забезпечення безпеки постачання газу $\epsilon$ ефективно організований внутрішній ринок газу, який не повинен мати зайвих фізичних або регуляторних бар'єрів для того, щоб газ міг переходити кордон у будь-який час до місця, де він найбільш необхідний. Для захисту від значних перебоїв газу необхідно суттєво посилити безпеку поставок газу в рамках прийняття безпеки газового регулювання поставок в країни СС.

У свою чергу країна повинна проаналізувати всі відповідні ризики, підготувати превентивні плани дій і надзвичайні плани щодо попередження кризи для кращого об'єднання ресурсів. Україна та країни СС повинні побудувати партнерські відносини, для досягнення єдиної мети, яка полягає в постачанні газу найбільш уразливим споживачам навіть у важких газових кризових ситуаціях. Водночас партнерська співпраця повинна бути спрямована на виявлення та будівництво нових маршрутів, які зменшують залежність країни від одного постачальника природного газу та інших енергетичних ресурсів.

Основною гарантією забезпечення безпеки постачання електроенергії повинна бути ефективна організація внутрішнього ринку електроенергії, що не має зайвих фізичних або регуляторних бар'єрів для того, щоб електроенергія могла перетікати кордон у будь-який час до місця, де вона найбільш потрібна.

Країні потрібно підтримувати запаси нафти 3 врахуванням показника середньоденного споживання, що повинно становити у залишку (запасу) із розрахунку у 90 днів.

Кібербезпека та захист критично важливої енергетичної інфраструктури $є$ ключовими у підвищенні стійкості енергетичної системи до серйозних збоїв, викликаних терористичними актами або кібер-атаками. Для вирішення проблем кібербезпеки пропонуємо прийняти рішення 3 врахуванням особливостей енергетичного сектору, зокрема вимог реального часу.

2 Інтеграція внутрішнього енергетичного ринку. Енергія повинна вільно протікати в межах країни без технічних або регулятивних обмежень. Тільки таким чином постачальники енергії можуть вільно конкурувати та забезпечувати найкращі ціни на енергію, можна повною мірою використовувати свій потенціал відновлюваної енергії. Ринок електроенергії вимагає фундаментальної переробки для інтеграції відновлюваних джерел енергії та технологічного прогресу. Поінформованість населення дає можливість споживачам підвищувати обізнаність щодо широкого вибору енергетичних послуг, зниження витрат i захисту споживачів. Інвестування в інфраструктуру, яка з'єднує країни, зробить потік енергії ефективнішим, поліпшить 
енергетичну безпеку, зменшить залежність від імпорту та підготує мережі для відновлюваної енергії.

Незважаючи на прогрес останніх років, потенціал європейської енергетичної системи досі не повністю використаний. Нинішня ринкова структура не генерує достатньо інвестицій, ринкова концентрація та відсутність конкуренції залишаються проблемою, а енергетичне середовище на європейському рівні все ще надто фрагментоване.

3. Економічний союз. Економічний і валютний союз координує економічну політику з метою забезпечення: можливості витримки майбутньої кризи завдяки економічним i соціальним реформам i відповідальній фіскальній політиці; стимулювання інвестиції та підвищення конкурентоспроможності; створення більшої кількості робочих місць і покращення умов життя. Зараз триває робота по зміцненню структури, яка дозволить їй швидше і рішуче реагувати на виклики в майбутньому. Метою Економічного союзу є забезпечення високого рівня добробуту для громадян усіх країн єврозони. Нагадаємо також той факт, що події в одній країні ЄС також впливають на інші країни.

4. Прогресивна політика для використання глобалізащії. У сучасній світовій економіці торгівля $\epsilon$ передумовою для зростання зайнятості та підвищення конкурентоспроможності товару, підприємства, регіону. Торгова політика сприяє створенню робочих місць та інвестиційних можливостей як для великих, так і для малих компаній. 3 точки зору споживчих пільг, торговельні угоди можуть знижувати ціни і пропонувати ширший асортимент при збереженні та заохоченні високих стандартів у сфері захисту прав споживачів, соціальних прав та екологічних норм. Збалансованість торгівлі та інвестицій відкриває ринки 3 нашими торговими партнерами, але й зміцнює глобальний вплив.

5. Правосуддя та основні права громадян. Кожен громадянин має ті ж основні права, які випливають з цінностей рівності, недискримінації, людської гідності, свободи і демократії. Ці цінності зміцнюються та захищаються верховенством права. Громадяни повинні без перешкод перетинати кордони не залежно від поставлених цілей: зміни місця проживання, праці, навчання або одруження в іншій країні, захищаючи особисті дані та покращуючи свої позиції як споживачі. Мир є одним 3 основних принципів і вимагає ефективної боротьби з тероризмом, торгівлею людьми та кіберзлочинністю, що безпосередньо випливає на сталий розвиток держави.

Ефективна побудова таких п'яти основних вимірів стимулює розвиток економіки, покращення фінансового стану та формування сталого розвитку. Доцільно відмітити, що мігращія як процес, сприяє сталому розвитку. Збалансована, всеосяжна та спільна міграційна політика допоможе скористатися майбутніми можливостями, одночасно вирішуючи наявні проблеми. Міграційна політика, яка наразі розробляється, будується на солідарності та відповідальності. Вона матиме додаткову перевагу - зробити цінний внесок у економічний розвиток і ефективність у довгостроковій перспективі [6]. Зрозуміло, що жодна країна СС не може зіткнутися з величезним міграційним потоком i не повинна залишатися наодинці з ними. Політика має на меті створити рамки для легальної міграції, повністю враховуючи важливість інтеграції в суспільство, що приймає. Заходи щодо правової імміграції охоплюють умови в’їзду та проживання для певних категорій іммігрантів, таких як висококваліфіковані працівники.

Підхід ЄС до міграції також вирішує питання інтеграції. Успішна інтеграція мігрантів у суспільство, що приймає, має важливе значення для максимізації можливостей, які надає легальна міграція та для реалізації потенціалу, який імміграція має для її сталого розвитку. 
116 Романчукевич В.В. Економічні напрями модернізації...

Постійний та надійний політичний підхід до управління міграцією також потребує вирішення проблеми нерегулярної міграції. Необхідно вирішувати це питання через конкретні заходи, спрямовані на роботодавців, які прагнуть та мають можливість створити гуманну та ефективну політику працевлаштування для мігрантів. Вона повинна бути орієнтована на мережі торгівлі людьми та контрабандистів, які користуються працею нелегальних осіб. Розбудова діалогу та партнерства 3 країнами походження та транзиту, заснованої на солідарності та спільній відповідальності, також $\epsilon$ важливим аспектом спільного підходу країн до міграції.

Отже, виходячи із проведених досліджень сформуємо основні індикатори економічного напряму фінансової політики сталого розвитку (табл. 1).

Таблиия 1

Індикатори економічного напряму державної фінансової політики сталого розвитку

Table 1

Indicators of economic direction public financial policy of sustainable development

\begin{tabular}{|c|c|c|}
\hline Показник & Напрям & $\begin{array}{c}\text { Найменування індикаторів у межах } \\
\text { напряму }\end{array}$ \\
\hline $\begin{array}{c}\text { Продуктивність } \\
\text { економіки та } \\
\text { припущення іï } \\
\text { подальшого розвитку }\end{array}$ & Економічні показники & ВВП на душу населення \\
\hline \multirow{3}{*}{$\begin{array}{c}\text { Раціональне } \\
\text { використання } \\
\text { природних ресурсів }\end{array}$} & \multirow{3}{*}{$\begin{array}{l}\text { Раціональне використання } \\
\text { невідновлюваних ресурсів }\end{array}$} & Видобуток енергетичної сировини \\
\hline & & $\begin{array}{c}\text { Видобуток неметалевих та будівельних } \\
\text { матеріалів }\end{array}$ \\
\hline & & Видобуток рудної сировини \\
\hline \multirow{6}{*}{$\begin{array}{c}\text { Використання енергії } \\
\text { та інструментів для } \\
\text { раціоналізації }\end{array}$} & $\begin{array}{c}\text { Виробництво } \\
\text { невідновлюваної енергії }\end{array}$ & $\begin{array}{c}\text { Частка невідновлюваної енергії у } \\
\text { валовому внутрішньому } \\
\text { енергоспоживанні }\end{array}$ \\
\hline & $\begin{array}{c}\text { Використання } \\
\text { відновлюваних джерел } \\
\text { енергії } \\
\end{array}$ & $\begin{array}{c}\text { Внесок електроенергії, виробленої } 3 \\
\text { відновлюваних джерел енергії }\end{array}$ \\
\hline & $\begin{array}{r}\text { Виробництво } \\
\text { електроенергії }\end{array}$ & $\begin{array}{c}\text { Виробництво електроенергії джерелами та } \\
\text { паливом }\end{array}$ \\
\hline & Енергоємність економіки & Енергоємність економіки \\
\hline & \multirow{2}{*}{$\begin{array}{l}\text { Кінцеве споживання } \\
\text { енергії }\end{array}$} & $\begin{array}{c}\text { Кінцеве споживання палива та енергії в } \\
\text { галузях економіки }\end{array}$ \\
\hline & & $\begin{array}{c}\text { Кінцеве споживання електроенергії в } \\
\text { галузях економіки }\end{array}$ \\
\hline $\begin{array}{c}\text { Виробництво та } \\
\text { управління відходами }\end{array}$ & $\begin{array}{c}\text { Виникнення та управління } \\
\text { РАВ та відпрацьованого } \\
\text { ядерного палива }\end{array}$ & Виробництво радіоактивних відходів \\
\hline \multirow{3}{*}{$\begin{array}{c}\text { Екологічний транспорт } \\
\text { людей і вантажів }\end{array}$} & $\begin{array}{l}\text { Транспортні показники } \\
\text { вантажного транспорту }\end{array}$ & Продуктивність вантажів \\
\hline & \multirow{2}{*}{$\begin{array}{c}\text { Ефективність } \\
\text { екотранспорту в складі } \\
\text { громадського транспорту }\end{array}$} & Продуктивність пасажирських перевезень \\
\hline & & $\begin{array}{c}\text { Проїхав відстань на душу населення } \\
\text { громадським транспортом }\end{array}$ \\
\hline
\end{tabular}

Джерело: систематизовано автором 
Індикатори економічного напряму фінансової політики сталого розвитку націлені на покращення економічного стану країни. Оскільки саме кожен із вказаних індикаторів вказує на зростання/зменшення рівня економічного стану. Традиційно економічний розвиток розглядається як мета і середовище як інструмент розвитку через використання природних ресурсів.

Поряд 3 цим, варто пропонуємо основні економічні напрями модернізації ДФПСР України, зокрема:

1. Покращення інвестиційного клімату. Для стимулювання інвестиції в Україні пропонуємо за доцільне зміцнити економіку та створити нові робочі місця. Цих цілей вдасться досягти за умови усунення бар'єрів для інвестицій, надання консультацій щодо потенційних проектів та розподілу коштів.

2.Формування єдиного ичифрового ринку. Інтернет і цифрові технології перетворюють наш світ. Однак існуючі онлайн-бар'єри перешкоджають доступу громадян до товарів і послуг, інтернет-компанії та стартапи мають обмежену сферу застосування, а підприємства та уряди не можуть повністю використовувати цифрові інструменти. Тому важливо сформувати єдиний ринок для цифрового віку шляхом усунення регуляторних бар'єрів та переходу від національних ринків до єдиного ринку.

3. Входження в структуру Європейського енергетичного союзу. Європейський енергетичний союз забезпечить безпеку енергії в Європі. Більш раціональне використання енергії, в той час як боротьба зі зміною клімату, є стимулом для створення нових робочих місць, зростання та інвестування в майбутнє Європи. Досвід показує, що прогрес досягнутий після прийняття Рамкової стратегії енергетичного союзу для переходу до низьковуглецевої, безпечної та конкурентоспроможної економіки.

Висновок. Для досягнення реального сталого розвитку необхідно створити послідовну державну політику у всіх їхніх формах (стратегії, закони, фінансові інструменти). Це може бути досягнуто шляхом прийняття рішень на основі фактичних даних та вдосконалення умов для участі громадськості для створення змістовного соціального діалогу.

Економічний розвиток $\epsilon$ дуже важливим елементом сталого розвитку, що дозволяє боротися з бідністю, змінювати свій розвиток тощо. Однак, економічне зростання не завжди обов'язково призводить до поліпшення сталого розвитку. Тільки економічне зростання зі зменшенням рівня екологічного впливу можна відстоювати як частину сталого розвитку. Іншими словами, економічне зростання та негативний вплив на навколишне середовище повинні бути розділені підвищенням екологічної ефективності.

Економічна політика та ринкові механізми повинні використовуватися для сприяння сталого розвитку, а не проти нього. Не заперечуючи важливість таких інструментів, як законодавство, інформування громадськості тощо, економіка $\epsilon$ потужним інструментом сталого розвитку. При належному використанні вона забезпечує ефективні стимули для вибору процедур, що відповідають політиці сталого розвитку.

1. Варченко О. М., Даниленко О. С., Шубравська О. В. Концептуальні основи сталого розвитку агросфери. Біла Церква : БНАУ, 2010. 160с.

2. Дорогунцов С. І., Ральчук О. М. Сталий розвиток і безпека: аспекти сполучення. К. : Знання України, 2002. 34 с.

3. Єфремов О. Сталий чи гармонійний (з екосистемою) розвиток - чому віддати перевагу? Економіка України. 2008. №2. С. 85-90.

4. Котикова О. І. Зміст поняття сталого розвитку. Науковий вісник Волинського державного університету імені Лесі Українки. 2007. №12. С. 170-174. 
118 Романчукевич В.В. Економічні напрями модернізації...

5. Мельник Л.Г. Сталий розвиток та екологічна безпека суспільства в економічних трансформаціях / за ред. д.е.н., проф. Хлобистова Є.В. / РВПС України НАН України, ІПРЕЕД НАН України, СумДУ, ЛНТУ, НДІ СРП. Сімферополь : Фєнікс, 2010. С. 142-160.

6. Малиновська О.А. Міграційна політика: глобальний контекст та українські реалії : монографія. К. : НІСД, 2018. 472 с

7. Про Основні засади (стратегію) державної екологічної політики України на період до 2030 року. URL : https://zakon.rada.gov.ua/laws/show/2697-19 (дата звернення: 25.11.2019)

8. Трегобчук В. М. Концепція сталого розвитку для України. Вісник НАН України. 2002. № 2. С. $28-40$

9. Шубравська О. Сталий економічний розвиток: поняття і напрям досліджень. Економіка України. 2005. № 1. С. $36-42$.

\section{References}

1. Varchenko, O. M, Danilenko, O. S, and O. V Shubravska. Conceptual bases of sustainable development of the agrosphere, BNAU, 2010.

2. Doroguntsov, S. I., and O. M. Ralchuk. Sustainable development and safety: aspects of communication, Knowledge of Ukraine, 2002.

3. Efremov, O. "Sustainable or harmonious (with ecosystem) development - why give it preference?" Economy of Ukraine, no 2, 2008, pp. 85-90.

4. Kotikova, O. I. "Content of the concept of sustainable development." Scientific Bulletin of Volyn State University named after Lesya Ukrainka, no. 12, 2007, pp. 170-174

5. Melnik, L. G. Sustainable development and environmental security of society in economic, ed. Khlobistova E.V., Phoenix, 2010, pp. 142-160.

6. Malinowska, O.A. Migration Policy: A Global Context and Ukrainian Realities, NISD, 2018.

7. "On the Fundamental Principles (Strategy) of the State Environmental Policy of Ukraine for the Period up to 2030. Verkhovna Rada of Ukraine, zakon.rada.gov.ua/laws/show/2697-19. Accessed 25 Nov. 2019.

8. Tregobchuk, V.M. "The concept of sustainable development for Ukraine." Bulletin of the National Academy of Sciences of Ukraine, no 2, 2002, pp. 28-40.

9. Shubravska, O. "Sustainable economic development: the concept and direction of research." Ukraine economy, no. 1,2005 , pp. $36-42$. 